\title{
İSTİKLAL HARBİ DÖNEMİNDE BATI ANADOLU'DA YUNAN ZULMÜ, 1921 (Arnold Toynbee'nin eşi Bayan Rosalind Toynbee'nin İzlenimleri)
}

Dr. Mustafa ÇUFALI*

İstiklal Harbi döneminde Yunanlılar'ın Batı Anadolu'yu işgalinden sonra Türkler'e karşı giriștikleri katliamlar, yağmalar ve yakıp yıktıklan köy ve kasabalar hakkında Türkiye'de ve Batı'da çok şeyler söylendi ve yazıldı. Batı'da yazılan eserlerden biri de ünlü tarihçi Amold J. Toynbee'nin "Western Question in Greece and Turkey" isimli eseridir" Toynbee, 15-26 Ocak ve 9 Ağustos-9 Eylül 1921 tarihleri arasında Yunanistan'ın çeşitli bölgelerinde, 27 Ocak-8 Ağustos ve 9-16 Eylül 1921 tarihleri arasında da İstanbul, İzmir ve Batı Anadolu'nun bir bölümünde incelemelerde bulunmuş, izlenimlerini yukarıda adı geçen eserinde kamuoyuna sunmuştu. Bununla birlikte gezi esnasında tuttuğu bazı notlar ve dostlarına gönderdikleri mektuplar henüz araștırmacılar tarafından yeterince incelenmemiştir. Bir kısmı bugüne kadar hiçbir yerde yayınlanmamıs Arnold Toynbee'nin Batı Anadolu gezisi esnasında tuttuğu notlar, yazdığı mektuplar, Büyük Millet Meclisi'nden aldığg gezi izinleri ve Türk devlet adamlarının kendisine verdikleri imzalı fotograflar Oxford'un Bodleian Kütüphanesi'nde araştırmacıların ilgisini bekliyor. Arnold Toynbee'nin eşi Rosalind de bu gezilerde kendisine eşlik etmiştir. Bayan Toynbee Batı Anadolu seyahati sırasında bazı notlar tutmuş ve bunların bir kısmını babası Gilbert Murray'e bir mektupla göndermiştir. Aşağıda çevirisini sunduğumuz Bayan Toynbee'nin babasına yazdığı mektup ve notlanı asıllan Oxford'daki Bodleian Kütüphanesi'nde mevcuttur. Mektup Toynbee'lerin 24-25 Mayıs 1921 tarihlerinde Yalova ve civanndaki incelemelerini konu ediyor. Arnold Toynbee de Yalova izlenimlerini 1 Haziran 1921'de İstanbul'da kaleme almış ve bu izlenimlerine yukarıda adı geçen kitapta da yer vermiştir ${ }^{2}$. Bu yazımızda Bayan Toynbee'nin

* $\quad$ Polis Akademisi, Araștırma Görevlisi.

1. Arnold J. Toynbee, The Western Question in Greece and Turkey. Second edition. London: Constable and Company Ltd., 1923.

2. Iki yazının karşılaştırmasına bakmak isteyenler için bak: age. sh. 299-311. 
mektubunun ve tuttuğu notlann çevirisini vereceğiz. Bunlar iki bölüm halindedir. İlk bölümü Bayan Toynbee'nin 28 Mayıs 1921'de yazdığı mektup, ikinci bölümü ise kendisinin Ağustos ve Eylül 1921'de tuttuğu notlardan oluşuyor.

Rosalind Toynbee (Bn. Arnold Toynbee)'den babası Gilbert Murray'e mektup ${ }^{3}$.

\section{KISSIYY ÖZEL VE GİLII}

İstanbul, 28 Mayıs 1921

Bu mektup ulaşıncaya kadar bizim Yalova'dan M.G.'a ${ }^{4}$ gönderdiğimiz telgrafı görmüş olacaksın (en azından göreceğine inanıyorum, çünkü bu konuda biraz tedirginliğimiz var). A. ${ }^{5}$ şu anda konu üzerinde makaleler yazıyor, ancak bütün olup bitenler ve yaşadıklarımız öylesine şaşırtıcı ve korkunç ki olayı mümkün olduğu kadar doğrudan ve tüm boyutlarıyla sana yazmak istiyorum. Sanırım bu durumla ilgili birşeyler yapabilirsin.

Önceki mektubumda duyduklanımı yazmıştım. Şimdi hepsi, hatta şüphelendiklerimizden daha fazlası teyit edildi.

İlk baştan başlarsak: Geçen Pazar (zannedersem bu ilkti) kendilerinden duyduğumuza göre Kızılay, Karamürsel Yarımadası'nın güney kıyısında 3.000 civarında mülteci kurtarmış, fakat oldukça büyük miktar da orada kalmış ve hâlâ da yarımadanın kuzeyinde bulunan Yolava'ya (İzmit yakınında) gitmeyi başaramamıșlar. Bize Fransız ve İtalyan Yüksek Komiserleri bunların kurtarılması konusunda istekli, hatta arzulu olduklarını, fakat devamlı itirazda bulunan İngilizler'den kaynaklanan büyük zorluklarla karşlaştıklarını söylediler. Ingilizler öncelikle nakil için deniz araçları eksikliklerinin olduğunu ileri sürmüşler. Kızılay, kendilerinin her zaman harekete hazır olan gemilerinin olduğunu söyleyince de İngiliz Yüksek Komiseri, kömür grevine bağlı olarak kömür yokluğunu ileri sürerek kendileri için gerekli olan gemilerden başkası için kömür veremeyeceklerini belirtmiş. Bu sefer Kızılay, gemilerinin Zonguldak’tan (ki kemalist bölgesidir) gelen Türk kömürünü kullandıklarını, kaldı ki bu kömürün baska milletlere verilmediğini, bu nedenle dünya üretiminden etkilenmediğini bildirmiş. Bunun üzerine de İngiliz Yüksek Komiseri, İstanbul'un mültecilerle yeterince dolduğu gerekçesiyle ve sağlık nedenlerinden dolayı daha fazla mülteci kabul edemeyeceklerini ileri sürmüş̧.

Neyse, ertesi sabah Kızılay'ın bir vapuruna sağ salim ulaştık ve orada iki Kızılay görevlisi, hanımları, bir doktor, üç Müttefik Devletler subayı ve geçen hafta Gemlik'in her tarafını bir müttefik komisyonu ile

3. Bodleian Library, Oxford, Department of Western Manuscripts, Toynbee Papers, Anatolian War, 1921-22, I. Box: 50, Folder: 1.

4. Ingiltere'de yaymlanan Manchester Guardian gazetesi.

5. Arnold Toynbee. 
dolaşan ve takdire şayan ve hoş bir kişi olan Uluslararası Kızılhaç temsilcisi M. Gehri' ile karşılaştık. M. Gehri bize Gemlik’te gördüğü ve inanılması güç şeyler anlattı.

Gemlik'te bir Yunan subayı, M. Gehri'ye katlettiği Türkler'in cesetlerini göstermiş, kendisine bunların öldürülme nedeni sorulduğunda da "öldürmenin daha iyi olacağını düşündüm” şeklinde cevap vermiş. M. Gehri ayrıca yakılıp yıkılan köyleri bizzat görmüş ve bunların failleri olan Yunan subayları ve çete liderleriyle karşılaşmıştı. Gehri, mutedil ve gün görmüş bir insan olmasına rağmen, tüm Müslüman nüfusun sistemli ve şeytanca metodlarla imhasına şahit olduğu için altüst olmuştu. Kendisi bu ayın 30'unda Cenevre'ye dönüyor ve bir hafta sonra da raporunu neşretmeyi ümit ediyor. Raporun bir nüshasını da bize göndermeye söz verdi. Kendisinden raporu senin adresine göndermesini rica ettim; bunla$\mathrm{r} 1$ istediğin gibi değerlendir ve ben gelinceye kadar benim için muhafaza et.

Gemlik katliamının ve tahrip edilen köylerin sayısını kendisinden alamadım, fakat tahminen Yalova bölgesi katliamı ve tahribatıyla aynı orantılıdır, ama daha büyük alanda ve daha büyük miktarda.

Yalova bölgesinde M. Gehri'nin rakamlanna göre 6 hafta önce 16 Müslüman köyü varken şu anda $13 / 4$ köy mevcut? ${ }^{7}$. 6 hafta önce Müslüman nüfus 7.000 iken şu anda hayatta kalabilen tahminen 1.500 ya da daha az kişi. Buna göre son 6 haftada sadece bir bölgede 5.500 civannnda Müslüman öldürülmüş demektir ${ }^{8}$. Bu bölgede şu ana kadar hiçbir askeri operasyon olmamıştır. Bu operasyon mahalli Rum nüfusun bir kısmından oluşan ve Yunan ordusuyla işbirliği yapan profesyonel eşkiyaların da katıldığı, silahlandırılmış Rum çetelerinin organizeli olarak, silahsız Müslüman nüfusun toptan katledilmesi operasyonudur. Gemlik'teki çete liderlerinden biri Yalova'da meşhur bir Rum imalatçı, diğeri de yumurta tüccarıymış.

Yalova'ya saat 2 civarında vardık. Burası Devonshire sahilinin bir parçası görünümünde, sırtını küçük yeşil dağlara dayamış, güneşli, şirin,

6. Maurice Gehri, Cenevre Uluslararası Kızılhaç Teşkilatı temsilcisi olarak Yunanlılar'ın Batı Anadolu'da yaptıkları katliamlan incelemek ve rapor hazırlamak üzere bölgeye gönderilmişti. Anadolu'dan dönüşünde bu raporu yayınlanmıştır. Gehri, Maurice, délégué du Comité International de la Croix Rouge: Mission d'enquéte en Anatolie (12-22 Mai 1921); Extrait de la Revue Internationale de la Croix Rouge, 3 Année, No. 31, 15 juillet 1921 (Geneva, 1921). Daha fazla bilgi için bak: Toynbee, The Western Question in Greece and Turkey, sh. 259, 278, 284-285, 317.

7. Mektupta geçen rakamı olduğu gibi verdik, fakat rakam anlaşılamadı. Amold Toynbee'nin notlarına göre 17 köyden 15.5'u tahrip edildi. Toynbee, Western Question. sh. 301 , dn. 1.

8. Bayan Toynbee bu cümleden sonra Ingilizce N.B. kısaltmasını kullanmıştır ki bu da "bundan sonra yazılanlara iyice dikkat et" manasındadir. 
sakin görünüşlü, neredeyse terkedilmiş intibaını veren küçük bir sahil kasabasıdır. Önce askerler bir kayıkla sahile çıktılar, nöbetçi kulübesini geçtiler ve evler arasında kayboldular. Her ne kadar dürbünle, sahilden daha içeride bir evin yanında bir grup asker görünüyorsa da burası hemen hemen terkedilmiş bir görüntü arzediyordu. Biraz sonra geri dönen kayıkla biz de karaya çıktık. Yunanlılar'dan tedarik ettiğimiz serbest giriş kartlarımızı nöbetçi kulübesine gösterdik ve zorlukla karşılaşmadan geçtik. Kızılay mensuplan ise sahile çıkma izni için bir müddet beklediler. Nihayet onlar da izin alıp başka bir kayıkla sahile çıktılar. Sorumlu Yunan subayı Giritli bir yüzbaşıydı ve görmesem inanamayacağım derecede haydut rolüne bürünmüş bir tiyatro sanatçısı görünümündeydi. Yüzünde o güne kadar hiç karşılaşmadığım ve bir daha hiç karşılaşmamayı ümit ettiğim apaçık ve kontrol edilemeyen korkunç bir kin vardi. Tüm resmi muameleler boyunca yüzünden kin ve öfke saçıllyordu ve burada hiçbir mülteci olmadığına yemin ediyordu. Bizimle beraber gelen üç subayı karşılamaya gelen bir teğmen, büyük bir heyecan ve huzursuzluk içinde "burada hiçbir mülteci yok, biz uygar bir orduyuz"!! dedi9.

O iki gün boyunca öfkelerinden şekilden şekile giren yüzleriyle, zaman zaman bize kendilerinin 'müttefik' subay ve uygar insanlar olduklarını söyleyip durdular.

Yüzbaşı, bize karşı akla gelebilecek her türlü engellemeye başvurdu. Önce hiçbir mülteci olmadığını söyledi. Daha sonra sadece 'yakılmış köylerden' (ilk defa köylerin yakıldığını kabul ediyorlardı), en sonunda da kendi listesinde işaretli birkaç köyden mülteci alabileceğimizi söyledi. Gemlik'e 10. Tümen Komutanı General Leonardhapoulos'a iki defa telgraf çekti. Telgrafa aldığı her cevaptan sonra tavırlarını daha da sertleştiriyordu. Her ne kadar sarih bir delile sahip değilsek te hiç şüphe yok ki herşeyi 10. Tümen Generali düzenliyordu. Tüm müzakereler saatlerce sürüyor, kaptan Yunanca'dan başka bir dil anlamıyor, bizim heyette de sorumluluk sahibi biri bulunmuyordu. Sözde sorumlu kişi oldukça iyi, fakat çok genç ve tecrübesiz bir İngiliz teğmendi. İtalyan da, hayat dolu ve oldukça iyi bir arkadaş olmasına rağmen çok genç bir teğmendi. FranS1z ise daha tecrübeli ve yetenekli bir yüzbaşıdı ve heyetin sorumluluğunu başarılı bir şekilde üstlenebilirdi. Fakat her nedense sorumluluk İngiliz teğmendeydi ve kendisi hem askeri polis, hem de tercümanlık vazifesini üzerine almıştı. Aralarında hiçbir ihtilaf yoktu ve özellikle Fransız yüzbaşının tavrı mükemmeldi. Fakat bu, otoritenin hiçbir kimsenin elinde olmadığı anlamına geliyordu. Bu nedenle müzakereler sonsuza dek uzuyor ve karışık bir hal alıyordu. İnanıyorum ki eğer başlangıçtan itibaren ipleri elinde tutan üst rütbeli bir subay olsaydı, Yüzbaşı Papagrigoriou çoktan yola gelirdi, fakat müttefiklerin sorumluları bizi bekleyen problemleri

9. Mektubun bundan sonraki bölümlerindeki kelime altı çizimleri ve ünlem işaretleri Bn. Toynbee'ye aittir. 
tahmin edememişlerdi ve subaylara sadece Kızılay'a eşlik etme işinde ihtiyaç duyulduğunu düşünmüşlerdi.

En enteresan şey küçük kasabanın nüfus ve atmosferindeki tedrici değişimdi. Kasabanın sakin görünümünün dikkatli bir şekilde hazırlandığını zannediyorum. Fakat öğleden sonra hava yavaş yavaş gerginleşmeye başladı. Halk ortaya çıkmaya başlayınca etraf dolmaya, karışmaya ve berbat bir hal almaya başladı. İkinci günün akşamı ortalık sanki cehennemi andirıyordu.

Sadece Yunan subaylan, askerleri ve onların yanında, müzakerelerimizin yapıldığı Hükümet Konă̆ı'nın karşısındaki kahvehanede sürekli oturan, mültecilerin arasında dolaşan, onları korkutup tehdit eden ve Albay'a tavsiyelerde bulunan, hatta emirler veren çeteler değil, aynı zamanda Rum, Ermeni bütün Hıristiyan ahali de yan-insan haline gelmiști. Sanki, kan içen korkunç vahşi bir hayvan yüzüne sahiptiler. Bütün ahali bir deliler topluluğunu andırıyordu. Öyle bir durum ki Conrad ${ }^{10}$ herkesten daha iyi tasvir edebilirdi. Sanki herkes tedricen bir hayvana dönüşmüs, sadece evcilleşmemiş vahşi bir hayvan değil, aynı zamanda iğrenç, gayrı tabii ve inanılması güç bir hayvan. Bu bölgedeki Türk kadınlanı hâlâ Meryem Ana gibi giyiniyorlar. Uzun mavi bir entari ve yüzlerinde beyaz bir peçe, tipik İtalyan Meryem Ana heykelini andınyorlardı. Oraya vanı̧ımızın ikinci günü bunların yüzlercesi, kucaklarında çocuklarıyla beraber saatlerce büyük bir sabırla oldukları yerde oturuyorlardı. Korkudan yüzleri kül gibi olmuştu ve aşırı bir sükunet ve sessizlik içinde duruyorlar, sadece çocuklar oyun oynuyor veya ağlıyordu. Hepsini deniz kenarında bir araya getirdik. Bazılarının sı ğırlan, tavuklanı ve rengârenk yatak-yorganlanı vardı. Bıyıklı, bronzlaşmış, sabırlı ve çileli yüzlü erkekleri de yanlarındaydı. Bunlar Misır'a hicret eden Kutsal Aileler'e benziyordu. Sahilin yukarısında demir parmaklıkların arkasında ise neşeli görünen, süslü giyimli, kahkaha atan ve alaylı bir şekilde bağıran 'hıristiyan' kadınlar vardi.

Arnold, Ermeni katliamı sırasında Türkler'in yüzlerinde de bu vahşi, garip bakışların olduğunu duyduğunu söyledi. Anlaşılıyor ki bu, katliamlara uygun bir olgudur.

Neyse, o ilk öğleden sonraya dönelim. Resmi görevliler üst katta tartışılarken, biz alt katta Kaymakam'ın odasında Kızılay temsilcileriyle beraberdik ve tuhaf bir komedinin hazırlanışına şahit olduk: Önde bir

10. Bayan Toynbee'nin sözünü ettiği kiși Ingiliz yazar Conrad olmalı. Joseph Conrad (1857-1924) ünlü Ingiliz romancılarından olup, aslen Polonya'lıdır. Ukrayna'da doğmuş, sonra Ingiliz vatandaşlı̆̆ına geçmiştir. Eserlerinin bir kısmı seyahat ettiği uzak memleketlerin durumları ve olaylarına aittir. Tabiat tasvirleri ve heyecan veren psikolojik tahlilleri ünlüdür. Ibrahim Alâettin, Meşhur Adamlar, Hayatları, Eserleri, Cilt: 1, Istanbul, 1933-1935, S. 247-248. 
Rum din adamı, arkada güllerle süslenmiş, Rum elbiseli üç kadın cesedi taşıyan bir araba göründü. Din adamını kanlı elbiseleri ve gülleri en uygun bir tarzda düzenlerken gördük. Daha fazla kan görünsün diye arabanın perdesini açmış, yaptığı işten memnun olarak ve ümitle görevlilerin bulunduğu pencereye bakarak doğrulmustu (Bu din adamı Komisyon'un gelmesinden iki gün önce İstanbul'dan gönderilmişti ve kendisi bize Patrikhane temsilcisi olduğunu söylemişti). Sonunda cesetler arabadan çıkarıldı ve yere kondu. Albay üç görevliyi cesetlere bakmak için dışarı çıkardı ve bunların Türkler tarafından öldürülen üç hıristiyan kadın olduğunu söyledi. Görevliler cesetleri selamladılar, fakat hiçbir yorum yapmadılar.

Türkler bize bunun bir mizansen olduğunu ve gösterilen cesetlerin de aslında Türk kadınları olduğunu söylediler ki doğruluğuna hepimiz inandık (Çünkü 1. Rahibin özenli bir şekilde hazırlığını kendi gözlerimizle gördük; 2. Hristiyan kalabalık gerçekten kendilerinden üç tane kadının öldürülmesi sonucu gösterecekleri tepkiyi göstermemişti; 3 . Türk ahali tamamen silahsızlandırılmıştı ve oldukça emindik ki isteseler bile tam bir terör ortamında üç Rum kadını öldürmeye cesaret edemezlerdi).

Bu hadiseden sonra Albay'ın General'ine çektiği ilk telgrafın cevabı$\mathrm{n} ı$ beklerken son iki köye gidip oradaki durumu görmeye karar verdik. Albay derhal itiraz etti ve yolun çok uzak olduğunu, gece yarısına kadar geri dönemeyeceğimizi, üstelik yolun çetelerle dolu, ağaçlıklı, dar bir vadiden geçtiğini, dolayısıyla emniyetimizi temin edemeyeceğini söyledi. Kendisine tatlı bir şekilde gülerek bunun kendimiz için mahzuru olmadığını bildirdik. Zaten A(mold), ben ve Gehri bir Yunan konvoyu olmadan gitmeyi daha fazla tercih ediyorduk. Çünkü yalnız başımıza olunca oradaki durumu daha iyi görme firsatımız olurdu. Fakat görevliler sorumluluklarının farkında olduklan için yanımıza 10 er ve 1 çavuş verdiler. Uzun bir yürüyüşle çok güzel bir sayfiyeyi geçtikten sonra nihayet Samanlı isimli ilk köye vardık. Köyün erkekleri iki sıra halinde ve her sıranın sonunda silahlı bir sivil Rum olduğu halde bizi bekliyordu. Bu silahlı Rum'un kim olduğunu sorduğumuzda hemen "kır bekçisi”" olduğunu söylediler. Aslında bunlar köylülere dehşet saçan, çatık kaşlı, vahşi birer çete mensubu idi. Eğer durum çok ciddi ve trajik olmasa bunlara bakan kişi gülmekten kendini alamazdı. Durumun farkına varamayan bizim küçük teğmen, etrafındaki Yunan korumalan ve çete mensubunun sert bakışlan altında Rum bir tercüman vasıtasıyla köylülere soru sormaya başladı. Köylülere bizimle beraber gitmek isteyen olup olmadığı soruldu ve yalnız bir kişi olumlu cevap verdi. Bu şekilde birkaç soru daha sorarak resmi prosedüre devam etti. Bu tür işlere alışkın olan $\mathbf{M}$. Gehri soruşturmanın değerini tamamıyla anlıyordu. Zannedersem Fransız Yüzbaşı da anlıyordu, fakat hiçbiri de Türkçe bilmiyordu. A(rnold) ile ben ise geride kaldı. A(mold) herkese adını ve kaç kişilik bir aileye mensup olduğunu sorup not alıyordu. Böylece köyün yerlileri ve diğer yakılan köylerden gelenle- 
rin sayısını tesbit etmeye başladı. Biraz Türkçe konuşarak köylülerin güvenini kazandıktan sonra "kır bekçisi" ve askerlere dönerek nazik bir şekilde konuştuklarımızın duyulamayacak kadar uzak mesafeye geri gitmelerini istedik. Bize kızgın gözlerle bakarak isteğimizi yerine getirdiler. Bundan sonra halka teker teker köyde kalmayı mı yoksa bizimle beraber gitmeyi mi arzu ettiklerini sorduk. Hepsi de ızdırap içinde bir fisıltıyla gitmek istediklerini söylediler. Hepsi de bizimle beraber gelmek istiyorlardi.

Daha sonra diğerlerinin yanına giderek duyduklanımızı anlattık. Bizim küçük teğmen oldukça şaşırmış ve üzülmüştü. Sonra ikinci köy olan Akkö̉y'e yola çıtık. Giderken yolun solunda büyük, müreffeh görünümlü bir Ermeni köyü vardı. Akköy'de de caddelerde hiç kimse görünmüyordu, ama burada da "kır bekçi”leri vardı. Yalnız bu seferki soruşturmamız daha sağlıklı oldu. Köyün hocası bizi evine götürdü. Kapıda bir İngiliz askeri polis beklerken biz sorulara başladık. Hoca çok vakur, sessiz ve çekingen duruyordu, fakat onu büyük bir korku içinde görmek çok üzücüydü. Kendisi Kızılay vapurunun geldiğini duymamıștı ve bizim de kim olduğumuzu ve niçin bu soruları sorduğumuzu bilmiyordu. Burada da Rum bir tercümanın dezavantajını anladık. Yine de yavaş yavaş öğrenmeye başladık ki, köyün hocası 9 gün önce öldürülmüş, kendisi de yakılmış başka bir köyden muhacir olarak gelmiş. Hocanın öldürüldüğü gece 60 kişi daha öldürülmüs. Bu nedenle tüm köy halkı büyük bir korku içinde ve buradan gitmek istiyorlardı. Kendisinden herşey dinlenilmeliydi. Hocanın kendi davranışlan ve korku içindeki hali buradaki korkunç durumu söylediği sözlerden daha iyi anlatıyordu. Sonraki gün kendisini bizimle beraber götürmek istedik. Cünkü büyük bir ihtimalle bize anlattıklarından dolayı öldürülecekti. Fakat kahramanlık örneği göstererek köylülerin tümünün gitmesi mümkün değilse kendisinin de onlarla beraber kalacağını söyleyip teklifimizi reddetti.

O akşam Akköy'de gördüklerimizin hepsi bu kadardı. Fakat ertesi gün İngiliz ve İtalya teğmenler, mültecilerin toplanmalanna nezaret etmek üzere gittikleri zaman, köyün arka taraflarına götürülmüştü. Buradaki binalar yağmalanmış ve yıkılmış, eşyalar, elbiseler sokaklara fırlatılmıştı. Evlerin arka avlulanında da yeni mezarlar vardı. O sabah gördükleri bizim küçük teğmen'i ikna etmiş, gözlerinin açılmasına ve değişmesine sebep olmuştu Arnold, herhangi bir katliama engel olmak için o gece mutlaka bu iki köyde birden kalmamız gerektiğine inanmıştı, fakat diğerleri bunun gerekli olduğu fikrinde değillerdi. Fikirlerine değer verdiğimiz M. Gehri de bunun doğru olmadığını söylüyordu. Gemlik'te gördüklerinden yola çıkarak Yunanlılar'da utanma duygusu kalmadığını, bizim köyde kalmamızın onları katliam yapmaktan en ufak bir şekilde bile caydırmayacağını, üstelik bizim hayatımızın da tehlikeye gireceğini söyledi. Bunun üzerine Arnold kendi başına köyde kalmak istediğini belirtti. Sonunda kendisini bu fikirden caydırdık. "Kır bekçileri”nin gözleri önünde 
herkese bu iki köyde yaşayanların tam listesini çıkardığımızı, bir gün sonra mültecileri alıp götürmek ve durumlarını kontrol etmek üzere tekrar geleceğimizi ilan ettik. En azından o gece köylüler için sakin geçmişti.

Akşam ve gece boyunca uzun bir yürüyüşten sonra saat 10.00 civarında Yalova'ya vardık. Yüzbaşı Papagrigoriou'nun gönderdiği telgrafa Gemlik'ten General Leonardhopoulos'tan cevap gelmişti. General Yüzbaşı'ya hiçbir yerli Müslüman'ın göç etmesine müsade edilmemesini em-

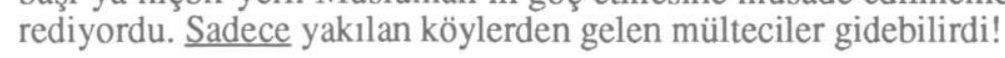

\section{BAYAN ARNOLD TOYNBEE TARAFINDAN TUTULAN NOTLAR}

Ağustos'un başında İzmir'e ulaştık. Arnold, Subat ayında yaptı̆̆ seyahatte tanıştıklarını büyük bir sabırsızlık içinde görmek ve onlardan mümkün olduğu kadar İzmir ve civarında olan bitenlerin gerçek hikayesini öğrenmek istiyordu. Özellikle de ilkbaharda Yunanlılar'ın geri çekilirken yaptıklan Yalova-Gemlik katliamından beri olanlan merak ediyordu.

Kuzeydeki tecrübelerinden sonra önceki ziyaretinde duydugu ve çok abartıldığı söylenen Yunanlılar'ın yaptıklan kötülükler hakkındaki çeşitli rivayetlere daha fazla önem vermeye başlamıştı.

Büyük bir sabırsızlıkla görmek istediği iki Türk'ten biri İzmir'den gitmişti. Fakat ismi Dr. Hüsnü Bey olan diğerini görmüştük. Hüsnü Bey bize İzmir içinde ve dışında yaşayan Türkler'in içinde bulunduklan terör ortamı ve hayat şartları hakkında çok kötü şeyler anlattı.

Şimdi Amold'un kendisini ilk ziyaret ettiği zaman konuştuğundan daha açık konuşuyordu. Çünkü o zaman Arnold, Yunanlılar tarafindan gezdirildiği için daha çok Yunan sempatizanı olarak biliniyordu. O zaman Türkler oldukça yakın davranıyorlardı, ama yine de çekingen olarak konuşuyorlardi.

Dr. Hüsnü bize Yunan işgali altında bulunan tüm bölgelerde sistematik bir şekilde katliam ve sürgünlerin yaşandığını, hâlâ da çok faal bir şekilde devam ettiğini söyledi. Arkadaşlanyla beraber bu olayları sürekli olarak rapor ettiklerini (kendilerine gelen tüm sikayetleri yerinde incelemişler ve ancak ispat edilebilen olaylan raporlarına yazmışlar) söyledi. Bu raporlan da zaman zaman İtilaf Devletleri konsolosluklanna sunmuşlar. Bu çalışmaya Mayıs ayı başında başlayıp Haziran sonuna kadar sürdürmüşler. Italyan Konsolosu'nun, İtilaf Devletleri konsoloslarının olayların farkında olduklanı, ayrıca araştırmalarını ısrarla sürdürülmesinin bir faydası olmadığı, aksine tehlikeli olması sebebiyle çalışmaya son vermeleri gerektiği şeklindeki tavsiyesi üzerine de çalışmalanna son vermişler. 
Dr. Hüsnü, Haziran sonundan itibaren de ancak doğrulamak için özel bir çalışmada bulunmadan, kendisinin dikkatini çeken hususları gelişigüzel not almış.

Bize anlattı̆g tüm vakaların önceden meydana geldiğini ve bize ispatlayabileceğini belirtti.

Dr. Hüsnü daha önce İzmir'in çok yakınında arazi sahibi önemli biriymiş. Ayrıca Türkler'in dışında Rum ve Ermeniler arasında da şöhreti olan hatırı sayılır doktorlardan biriymiş. Kendisini Arnold'la tanıştıran da yıllardan beri dostu olan ve kendisini çok sayan Amerikan Misyoner Koleji Müdürü Dr. McLaughlan'mış. Kendisine sorduğumuz tüm sorulara "Hüsnü'ye sorun. Ona kesinlikle güvenebilirsiniz" demişti.

Dr. Hüsnü'nün kendi kır evi olan Çizmelizade, birkaç ay önce ilişkilerinin çok iyi olduğu Rum köylüleri tarafından (kendisi bazı Rum çocuklarının manevi babası olarak kabul edilmesine ve bazı Rumlar'ı uşak ve işçi olarak hizmetine almasına rağmen) yağma edilmiş ve sonra da yakılmıştı. Malları harap edilmiş, dolayısıyla tamamen iflas etmişti. Hâlâ Rumlar'dan tazminat almaya çalışıyordu.

Kendisi iki defa şüphe üzerine hapishaneye atılmış, ancak İtalyan Konsolos'un araya girmesiyle serbest bırakılmış. Sonunda İtalyan tabiiyetine geçmiş ve bu yüzden hafta içi güvenliğe kavuşmuştu. Fakat Pazar günleri konsolosluk kapalı olduğu için saklanmak zorunda kalıyordu.

Bir müddet önce bir Pazar günü gün ortasında İtalyan tabiiyetinden biri Yunanlı bir jandarma tarafından tutuklanmıș, Pazartesi ve daha sonra konsolosun tüm girişimlerine rağmen bir daha kendisinden haber alınamamıştı.

Aşağıdaki tüm anlatılanlar Dr. Hüsnü'nün kendi sözleridir. Dr. Hüsnü, samimi ve mutedil biri olarak (kelimelerine çok dikkat ediyor, olayların kendisinin tahkik edemediği bölümlerini titizlikle işaret ediyordu) bizim üzerimizde iyi bir etki bıraktı. Şaşırtıcı olan şey, kendisinin anlattığı olaylarla bizim Izmit ile Gemlik arasındaki bölgede şahit olduğumuz olaylanı, bazan çok küçük ayrıntılarına varıncaya kadar, birbirine çok benzemesi ve bu bölgede sistematik olarak yapılan mezalimin tüm bölgelerde aynı anda başlamasıydı.

\section{KATLIAM VE YAĞMA}

Yurdun tüm bölgelerinde düzensiz Rum çeteleri oluşturulup Yunan yetkililer tarafından silahlandırıldılar. Bu çeteler bilhassa ilkbaharda Yunan ordusunun Kovalıca'dan çekilmek zorunda kaldığı günden beri faaliyetlerini artırmış durumdalar. Bunlar köylere saldırıyorlar, yağmalayıp yıkıyorlar ve katliam yapıyorlar. Bu çeteler bu faaliyetlerini bazan düzen- 
li Yunan kuvvetleriyle beraber, bazan da yalnız başlarına yapıyorlar. Fakat her iki durumda da düzenli kuvvetler ve yetkililerin suç ortağı olduğunda pek şüphe yok. Bazı Ermeni çeteler de mevcut ve bunlar da Rumlarla işbirliği içindeler. Saldınların vahșeti ve kusursuzluğu farklı derecelerde oluyor. $\mathrm{Bu}$ da çete reislerinin kaprisleri ve insanlığına göre değişiklik gösteriyor. Bazı durumlarda sadece yağma ve yakmayla yetiniyorlar; fakat bazan da katliamlar oldukça özenli bir şekilde uygulanıyor (Bu anlatılanlar bizim İzmit ve Gemlik arasında da yaygın bir şekilde gördüklerimize tıpatıp uyuyor).

Aşağıdakiler Dr. Hüsnü'nün listelerinden aldığım birkaç örnek:

Mayıs ve Haziran aylarında

$\underline{\text { Sarlarlit }}{ }^{11}$

Kurtulmus.

Kayganlı,

Kobasdere.

Kepeçinar $^{12}$

köyleri bu yolla saldırıya uğramış, tamamen talan edilmiş ve tüm nüfus katledilmiştir.

$\underline{\text { Pekmezci }}^{13}$,

Kadıdağı.

Kömürcü ${ }^{14}$,

$\underline{\text { Selçikli }}^{15}$

köyleri talan ve tahrip edilmiş ve önceki köylere göre daha az olarak nüfusun tamamına yakını katledilmiş.

Soğandere nahiyesinde 25 ile 30 arasında köy harap edilmiş ve tüm nüfusu katledilmiş.

Akhisar'la Manisa arasında 82 köy aynı şekilde tahrip edilmiş ve nüfus farklı oranlarda katledilmiş. Bazı köyler yakılmış.

2 Mayıs veya civarında aşağıdaki köy ve kasabalar saldırıya uğrayıp talan edilmiş:

11. Mektupta Savilar olarak geçiyor.

12. Tüm aramalara rağmen bu isimde bir köy veya mahalle bulunamadi. Sadece Muğla'nın Marmaris ilçesi yakınlanında Keçipınan isimli bir mevki var, ama mek-

tupta sözedilen köylere çok uzak.

13. Mektupta Pelmezli olarak geçiyor.

14. Mektupta bu köyün ismi Komerji olarak geçiyor.

15. Mektupta Seljuklu olarak geçiyor. 
Aydin.

Eğrek $^{16}$,

İsafakıhlar,

Arzular.

Karabă̆

Karapinar.

Aligozi ${ }^{17}$,

Kızılcaköy,

Șenköy ${ }^{18}$,

Balıkköy,

Bu köyün sakinlerinin bir kısmı katledilmiş diğerleri ise ormana kaçmiştır.

\section{Haziran'da}

Gördes ve Kayacık tamamen talan edilmiş ve yakılmış.

24 Haziran'da Yunan askerleri ve Ermeni çeteleri Akhisar yakınındaki Başlamıs köyünü kuşatmışlar, 12 ila 60 yas arasındaki köy sakinlerini toplayıp hemen hepsini katletmişler. Bunlardan 4 tanesi öldürülmeden önce dövülmüşler.

6 kişi (3'ü kadın) üstüne sıcak ütüler bastırılarak öldürülmüş $(\mathrm{Bu}$ haber katliamdan kurtulanlardan biri tarafından anlatılmıştır).

26 Haziran'da Yunanlılar, Tire civarında 18 köyü abluka altına alarak farklı derecelerde talan edip yakmışlar. Bu 18 köyün bazıları şunlardir:

Uzgur (Basköy) ${ }^{19}$,

Karakilise $^{20}$,

Toparlar ${ }^{21}$,

Mehali $^{22}$

16. Mektupta Irekkeui olarak geçiyor.

17. Tüm aramalarımıza rağmen bu veya buna benzer bir isimde bir köy veya mahalleye rastlayamadik.

18. Mektupta Charnkeu olarak geçiyor

19. Mektupta Uzguun olarak geçen Uzgun'un ismi şu anda Başköy'dür.

20. Karakilise ismi haritada bulunamadı. Yalnız sözü edilen civarda Akmescit ismiyle bir köy bulunabildi.

21. Mektupta Toparlah olarak geçiyor.

22. Bu veya benzer isimde bir yerleșim birimi bulunamad. 
Musalar.

Bozköy,

Yemisler,

Ispatlar $^{23}$

Camköy.

Ortaköy,

Dağdere,

Dağdere'de Hacı Ali Ağa isimli meşhur biri tüm ailesiyle beraber öldürülmüs, diğer köylüler kaçarak kurtulmuşlar. Yunanlılar kaçanlara bannacak yer verenlerin cezalarını çekeceğini ilan etmissler. Bu uyarılara rağmen Tire'de Ispatlı Hacı Süleyman'la birlikte bir kişi daha 2 mülteciye sığınacak yer vermiş. Mültecilere sığınacak yer veren bu iki kişi yakalanıp savaş suçlusu olarak sınır dışı edilmiş. $\mathrm{O}$ zamandan beri bu iki kişiden haber alınamamış.

\section{Sinır D1S1 Edilmeler}

Türk siviller, özellikle de eşraf, işgal altındaki birçok kasaba ve köyden toplanıp "Savaş Suçlusu” olarak götürülüyorlar.

Bu tutuklular hemen her gün gruplar halinde İzmir'e götürülüyorlar ve sonra da ortadan kayboluyorlar. Bunların Yunanistan'a sürgün edildiği tahmin ediliyor, fakat hiçbirinden haber alınamıyor. Bir kısmının ise cesetleri bulunuyor.

Bu sınır dışı edilmeler aşağıdaki bölgelerde meydana gelmiştir:

Kasaba,

Manisa,

$\underline{\mathrm{Nif}}^{24}$,

Alaşehir,

Salihli.

Ușak.

Kula,

Marmara,

Akhisar.

23. Bu veya benzer isimde bir yerlesim birimi bulunamadı.

24. Nif' in şimdiki ismi Kemalpaşa'dır. 
Tire.

Ödemis,

Bayındır.

Torbalı,

Aydin,

13 Nisan'da Salihli'de. Başsavc1, Müftü, Hakim ve diğer 25 eşraf, savaş esiri olarak tutuklandılar ve önce İzmir'e sonra da Yunanistan'a gönderildiler.

16 Nisan'da Uşak'ta müftü ve 20 eşraf, aynı şekilde tutuklanıp İzmir yoluyla Yunanistan'a gönderildiler.

20 Nisan'da Aydın yakınında Sultanhisar, Erbeyli, Koshli25, Umurlu, Germencik ve Balatcık ${ }^{26}$ köylerinde 80 kisi savas esiri olarak tutukland1lar. İçlerinden Köşk'lü Ömer Efendi'nin cesedi Köşk ile Aydın arasında, Rıza Efendi isimli başka birinin cesedi de Ömerli'de bulundu. Diğerlerinden ise hâlâ bir haber yok.

21 Mayıs'ta Aydın yakınlannda Karapınar'da aralarında Belediye Başkanı'nın da bulunduğu 50 eşraf toplanıp İzmir'e götürüldüler. Haklarında hâlâ bir haber yok. Akşamleyin Yunanlı subaylar, sürgüne gönderilen eşrafın evlerine gelip kadınlara sarkıntılık ettiler. Ertesi sabah ta değerli eşyalarını almak için halkı demir kamçılarla dövdülür.

2 Mayıs'ta Nazilli ve Atca'da 32 kişi tutuklanıp önce Aydın'a sonra da İzmir'e gönderildiler. Haklarında başka bir haber yok. Daha sonra Yunan çavuşlar sürülen kişilerin evlerine gittiler ve aynı olaylar yaşandı (demir kamçılar dahil).

Alasehir'de Kaymakam Rifat Bey, Yunan kumandana Yunan kuvvetlerinin çeşitli tecavüzlerini şikayet eden ardı ardına beş rapor gönderdi. İlk başvurusuna şikayet konusu olayların düzeltileceğine dair yatıştıncı bir cevap aldı, fakat herhangi bir işlem yapılmadı. Diğer şikayetlerine cevap bile verilmedi.

Yunan askerlerinin aşırılıklanı devam edince İzmir'deki İtalyan Konsolos'a raporlarının kopyasını ekleyerek ve durumu açıklayarak bir yazı yazdi.

25. Haritada Koshli veya benzer bir isim bulunamadi. Yalnız anlatılanlara ve takip edilen güzergaha bakılırsa sözü edilen yer Köșk olması gerekir. Bu nedenle yazının bundan sonraki bölümünde Koshli yerine Köşk kullanılacaktır.

26. Mektupta Balatch olarak geçiyor. 
İtalyan Konsolos, İzmir'deki Yunan yetkililerine durumu iletti, fakat onların cevabı sadece Kaymakam, Müftü ve Alaşehir'in 25 önde gelen kişisini tutuklayıp sınır dışı etmek oldu.

Kaymakam'ın raporları İtalyan Konsolosluğu'nda (25 Nisan'dan başlayarak) 20, 22, 24, 26, 84 numaralı dosyalardadır.

$\underline{\text { Kilisman }}^{27}$,

Sivrihisar.

Urla,

Torbalı,

Seydiköy ${ }^{28}$,

Cumaovas1,

(bu yerlerin her biri birkaç küçük köyün merkezidir) bölgelerinde, 15 ilâ 60 yaş arasındaki tüm köylüler bir Yunan subayının kontrolünden geçmek için her gün merkez köylere gelip kendisini takdim etmek zorunda tutulmuşlardı. Böylece tüm çalışma gününü kaybetmiş, dolayısıyla da ziraatini heba etmiş oluyorlardı.

Yeterince zengin olanlar ise Yunan subayına rüşvet vererek bu angaryadan kurtulabiliyorlar.

Kasaba,

$\underline{\text { Salihli. }}$

Alașehir.

Ödemis

Akhisar'da çiftçiler tarlalanna gidip çalışmaya cesaret edemiyorlar. Cesaret edenler ise ortadan kayboluyorlar.

18 Mayıs'ta savaş esirleri tarafından (bunların büyük bir kısmı Mısır'daki İngiliz savaş esirleriydi ve evlerine dönerken Yunanlılar tarafından yakalanmışlardı) İtalyan konsolosa bir dilekçe yazılmış. Bu adamlar yeterli havası olmayan yerde günde 18 saat çalışmaya zorlandıklarından, bir kısmının ise havasızlıktan öldüklerinden şikayet ediyorlardı.

Dr. Hüsnü'nün bu “tetkik edilmiş vakaları" Haziran sonundan ötesini içermiyor. Çünkü Haziran sonunda (himayesinde bulunduğu) İtalyan Konsolos kendisine bu raporlan hazırlaması sebebiyle boşuna bir tehlikeye maruz kalacağını bildirmişti. Fakat bizim ziyaret tarihimizde (Ağustos

27. Tüm aramalara rağmen bu veya yakın bir isimde bir yerleşim birimi bulunamadı.

28. Seydiköy'ün şimdiki ismi Gaziemir'dir. 
başı) durumun eskiye göre daha kötü olduğu ve yukarıda anlatılan mezalimin hemen her gün işlendiği konusunda teminat verdi.

Açıktır ki İzmir'dekiler dahil; Türk nüfusu terör ortamında hayatını devam ettiriyor.

\section{İzmir'deki Hapishaneler ${ }^{29}$}

Birçok Türk tarafından hapishanelerin çok kötü vaziyette olduklan söylendiği için mümkünse görmeye karar verdik. Öncelikle en berbatlan olarak tarif edilen "Maltesica" denilen hapishaneye gittik. Burası Maltız sokağında bir hapishaneydi. Normal bir hapishane değildi. Metruk ve Yunan yetkililer tarafından kapasitesinin üzerinde ve hapishane olarak kullanılan bir ambardı. Öğleden sonra saat 2.00 'de kapıya vardık, fakat yetkililer saat 3.00 'te içeri girebileceğimizi söylediler. Şaşırmış görünüyorlardı, ama bize en ufak bir şüpheyle bile bakmıyorlardı. Saat 3.00'te tekrar geldiğimizde şaşılacak bir şekilde bizi hemen içeri aldılar. Bizi doğrudan hakkında bize bahsedilen zemin kata götürdüler. Burası tabanı uzun taşlarla döşenmiş, pencereleri demir parmaklıklı ve çok kirli bir yerdi. Bizim ziyaretimiz esnasında burada 45 kişi vardı, fakat sayıları bazan 100 kişiye kadar çıkıyormuş. Buradakilerle demir parmaklıklar arkasında konuşmaya başlarken, içeridekiler bir kafesteki hayvanlar gibi parmaklıklara doluştular. Bizimle ilk konuşan İzmir eski valisinin yeğeni ve eski bir subaydı. Gelibolu'da tutuklanmıs. İngilizce'yi iyi konuşuyordu. Kemalistlerle fikir birliği içinde olduğu (kendisi bunu yalanlıyor) şüphesiyle hapiste tutuluyormuş. Mahkemeye çıkarılmak istiyormuş, ama ümidi de yokmus. 3 haftadır hapishanedeymiş, son iki haftadır da dizanteri hastasıymış. Sürekli olarak doktor istiyormuş, ama henüz doktorun yüzünü bile görmemiş. Hapishanedekilere günde yarım ekmek ve yetersiz miktarda su veriliyormuş. Daha fazla su istiyorlarmış, ama verilmiyormuş (aylardan Ağustos idi ve çok sıcaktı). Hapishanenin sağlık şartlan çok kötüydü ve oda da hiç havalandırılmamış ve temizlenmemişti. Taş zeminin üstünde birkaç yırtık ve kirli kilim parçalan hariç hiçbir örtü yoktu. Konuştuğumuz adam sanki bir hayalete benziyordu. Diğerleri de hasta görünümlüydü. Konuştuğumuz ikinci adam bir Ermeniydi ve sert bir Amerikan aksanıyla konuşuyordu. Kendisinin Amerikan vatandaşı olduğunu iddia ediyordu (Zannedersem bu doğru değildi, ancak Amerika'da yaşamıştı). Kendisiyle beraber 15 Ermeni daha bir Amerikan firmasında çalışırlarken birkaç gün önce Amerikalı'nın yurt dışına gitmesinden hemen sonra tutuklanmışlardı. Kendisine yapılan muameleye büyük bir öfke duyuyordu ve Türk subayının söylediklerini teyit ediyordu. Bir sonraki tutuklu Avusturalyalı bir denizciydi ve karada kafayı çekerken gemisi kendisini bırakıp denize açılmıştı (kendisi sonradan konsolosluğunun

29. Izmir'deki hapishaneler hakkında Amold Toynbee'nin izlenimleri için bak: Toynbee, a.g.e., s. 204-207. 
sorumluluğuna bırakılmak üzere İstanbul'a gönderildi). Redingotlu, hasır şapkalı, asik yüzlü ve olağanüstü görünümlü biri, bizden biraz uzak duruyordu ve bizimle konuşmaya gelmemişti. Kendisinin, askerlik hizmetinden kaçmış! 41 yaşında bir Yunan olduğunu söylediler. Geri kalanların hepsi Türk'tü ve çoğunlukla çiftçiydi. Burada bulunma süreleri de farklı farkliydı.

Gardiyanlar tutuklulanı yaptıklan şikayet dolu konuşmalan işitmiş olmalarına rağmen konuşmamıza aldını̧ etmediler. Öyle görülüyordu ki olan biteni eğlenceli buluyorlardı. Daha sonra Arnold, merkez hapishaneye gitti. Burası önceden normal bir Türk hapishanesiydi, güzel bir şekilde inşa edilmişti. Fakat Arnold, burada fazla birşey göremeden ve bilgi alamadan geri döndü. Sadece, hakkında daha önce bilgi sahibi olduğu iki özel tutukluyla görüşebildi, fakat bu görüşme de uzaktan, yüksek sesle ve bağırarak gerçekleşti.

Hapishanenin kötü şartlan ve pisliği hakkında da birçok şikayetler duyduk.

20 Eylül 